COSTING:Journal of Economic, Business and Accounting

Volume 4 Nomor 2, Juni 2021

e-ISSN : 2597-5234

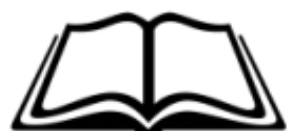

DMeEp

\title{
PENGARUH RASIO PROFITABILITAS, LIKUIDITAS, DAN SOLVABILITAS TERHADAP PERINGKAT OBLIGASI SYARIAH (SUKUK)
}

\section{THE EFFECT OF RATIO OF PROFITABILITY, LIQUIDITY AND LEVERAGE ON SHARIA BOND RATING (SUKUK)}

\author{
Frivanty Ekatiarta Nuriman ${ }^{1}$, Dian Hakip Nurdiansyah ${ }^{2}$ \\ Universitas Singaperbangsa Karawang, Karawang ${ }^{1,2}$ \\ Frivanty.Nuriman16120@student.unsika.ac.id ${ }^{1}$
}

\begin{abstract}
This study aims to determine the effect of ratio profitability, liquidity and leverage on sharia bond rating (sukuk). The research method in this study uses a quantitative apporoach. There were 13 companies that were used as populations in this study and by using a purposive sampling technique 4 sampels were also obtained. The statistical methods taken in the study are multiple regression analysis using classic assumption test. Based on the variable T test of profitability, it obtained $t_{\text {count }} 2.974>t_{\text {table }} 2.030$ and significant value of $0.004<0.05$. It means that return on asset positively and partially affected sukuk rating. Liquidity obtained $t_{\text {count }}-8.927<t_{\text {table }} 2.030$ and significant value of $0.000<0.05$. It means that Current Ratio partially affected sukuk rating. Leverage ratio obtained $t_{\text {count }} 3.362>t_{\text {table }} 2.030$ and significant value of $0.001<0.05$. It means that Debt to Equity Ratio partially affected sukuk rating. Furthermore, analysis of F test obtained $f_{\text {count }} 26.800>f_{\text {table }} 2.76$ and significant value obtained was $0.000<0.05$ which means that independent variable simultaneously affected sukuk rating.
\end{abstract}

Keywords: Profitability, Liquidity, Leverage and Rating Sukuk

\begin{abstract}
ABSTRAK
Penelitian ini bertujuan untuk mengetahui pengaruh dari rasio profitabilitas, likuiditas dan solvabilitas terhadap peringkat obligasi syariah (Sukuk). metode yang digunakan dalam penelitian ini menggunakan pendekatan kuantitaif. Terdapat 13 perusahaan yang dijadikan populasi dalam penelitian ini dan dengan menggunkaan teknik pengambilan sampel, purposive sampling diperoleh sebanyak 4 perusahaan. Metode statistik yang digunakan dalam penelitian ini yaitu analisis regresi linear berganda dengan memakai uji asumsi klasik. Berdasarkan uji $\mathrm{T}$ variabel profitabilitas memperoleh hasil $t_{\text {hitung }}$ 2,974 $>t_{\text {tabel }} 2,030$ dan nilai signifikan sebesar $0,004<0,05$. artinya secara parsial return on asset berpengaruh positif dan terhadap rating sukuk, likuiditas memperoleh hasil thitung $8,927<t_{\text {tabel }} 2,030$ dan nilai signifikan sebesar $0,000<0,05$. artinya secara parsial current rasio berpengaruh terhadap rating sukuk Rasio solvabilitas memperoleh hasiil $\mathrm{t}_{\text {hitung }} 3,362>\mathrm{t}_{\text {tabel }} 2,030$ dan nilai signifikan sebesar $0,001<0,05$. artinya secara parsial debt to equity berpengaruh terhadap rating sukuk. Kemudian hasil analisis pada uji $\mathrm{F}$ memperoleh hasil bahwa nilai $f_{\text {hitung }} 26,800>f_{\text {tabel }} 2,76$ dan nilai signifikan yang diperoleh sebesar $0,000<0,05$ yang artinya variabel independent secara bersama-sama berpengaruh terhadap peringkat sukuk.
\end{abstract}

Kata Kunci : Profitabilitas, Likuiditas, Solvabilitas dan Peringkat Obligasi Syariah 


\section{PENDAHULUAN}

Beberapa tahun terkahir pertumbuhan dan perkembangan sistem ekonomi berbasis syariah (Islam) di Indonesia mengalami pertumbuhan yang sangat pesat. Hal ini dapat terlihat dari banyaknya industri Syariah yang mulai muncul di Indonesia. Khususnya dalam industri keuangan, baik perbankan maupun non perbankan. Sektor Syariah yang mengalami perkembangan yang pesat di Indonesia adalah sektor perbankan, asuransi dan pasar modal Syariah (Mardiah et al, 2016).

Sistem ekonomi berbasis syariah khususnya pada industri pasar modal memiliki peluang dan tantangan tersendiri, konsep keuangan dalam sistem ekonomi Syariah didasarkan pada ajaran agama islam yang berlandaskan pada Al-Quran dan AlHadist, sehingga dalam transaksi yang dijalankan dalam kegiatan pasal modal Syariah yaitu harus berlandaskan dengan prinsip-prinsip Syariah sesuai syariat islam sehingga terbebas dari riba ataupun hal yang dilarang oleh agama. Saat ini perkembangan pasar modal Syariah di Indonesia mengalami perkembangan yang cukup baik. Meskipun perkembangan pasar modal Syariah tidak secepat perbankan Syariah tetapi memiliki kecenderungan yang terus meningkat setiap tahunnya, sejalan dengan berkembangnya industri keuangan Syariah di Indonesia.

Perkembangan pasar modal Syariah dapat ditunjang karena institusi pasar yang semakin menguat setiap tahunnya dan instrument investasi yang semakin beragam. Pasar modal Syariah memiliki manfaat untuk meningkatkan efisiensi alokasi sumber dana, meningkatkan penerimaan negara, dapat memperbaiki struktur modal bagi perusahaan dan dapat mengurangi ketergantungan terhadap hutang luar negeri pada sektor swasta. saat ini pasar modal Syariah sudah menerbitkan 3 macam produk, yaitu reksadana Syariah, saham Syariah atau yang lebih dikenal dengan sebutan Jakarta Islamic Index (JII), dan obligasi Syariah (sukuk). Produk pasar modal yang digunakan dalam penelitian ini adalah obligasi Syariah atau yang biasa dikenal dengan sebutan sukuk. Menurut Azzatilah \& Prajawati (2019) menyatakan bahwa Sukuk berasal dari Bahasa Arab "Sak" (tunggal) dan "sukuk" (jamak) yang dalam istilah ekonomi berarti suatu instrument hukum, akta atau bukti kepemilikan. Dalam ketentuannya sukuk didefinisikan sebagai surat berharga yang didalamnya mengandung kontrak pembiayaan berdasarkan dengan prinsip-prinsip Syariah.

Obligasi Syariah ( sukuk ) saat ini menjadi salah satu instrument investasi berbasis Syariah yang sedang tren di pasar modal Indonesia, Sukuk dipandang sebagai salah satu investasi yang lebih baik dibandingkan berhutang. Karena, sukuk memiliki risiko yang lebih kecil apabila dibandingkan dengan pinjaman konvensional dan sukuk cenderung mempertahankan korelasi dinamis yang lebih rendah dalam jangka Panjang. selain itu sukuk memiliki karakteristik tersendiri, yaitu didasari dengan prinsipprinsip Syariah sehingga dana akan aman dan tidak terlibat dalam spekulasi berlebihan (Qizam \& Fong 2019).

Saat ini perkembangan obligasi Syariah di Indonesia mengalami perkembangan yang cukup baik, Perkembangan sukuk di Indonesia yang setiap tahun memiliki perkembangan yang cukup pesat dikarenakan para investor tetarik untuk berinvestasi pada obligasi Syariah (sukuk), para investor 
tersebut bukan hanya para investor muslim melainkan investor non muslimpun memiliki ketertarikan untuk berinvestasi pada alternatif investasi ini. Hal yang patut diperhatikan oleh para investor dalam melakukan kegiatan investasi sebelum mengambil keputusan adalah dengan melihat peringkat obligasi Syariah perusahaan tersebut.

Menurut Widiastuty (2017)

menyatakan bahwa metode yang digunakan dalam pemeringkatan obligasi Syariah tidak jauh berbeda dengan obligasi konvensional. Peringkat sukuk merupakan suatu indikator ketepatan waktu pembayaran pokok utang dan bagi hasil pada para investor atas obligasi Syariah yang diperdagangkan oleh suatu perusahaan. Peringkat sukuk yang telah diberikan oleh rating agency akan menyatakan apakah obligasi Syariah berada pada kategori investment grade atau obligasi Syariah yang diperdagangkan berada pada kategori non-investment grade.Peringkat obligasi Syariah yang termasuk dalam kategori investment grade yaitu memiliki peringkat AAA, AA, A dan BBB sedangkan obligasi Syariah yang termasuk kedalam kategori non-investment grade memiliki peringkat $\mathrm{BB}, \mathrm{B}, \mathrm{CCC}$ dan $\mathrm{D}$. Peringkat sukuk suatu perusahaan sangat penting untuk diketahui oleh investor sebagai alat yang dijadikan untuk mengukur risk and return atas investasi yang dilakukan dalam suatu perusahaan (Utami ,2018). Semakin baik peringkat sukuk yang diterbitkan oleh suatu perusahaan maka akan semakin rendah tingkat risiko kegagalannya. Peringkat sukuk dapat dipengaruhi oleh risiko default. Risiko default adalah risiko yang terjadi karena adanya kemungkinan gagal bayar (Hassan et al. 2018).

Oleh karena itu dari rating sukuk inilah kita dapat mengambil suatu keputusan apakah investasi yang kita pilih merupakan investasi yang yang baik dan menguntungkan ataukah sebaliknya, dan rating sukuk ini dapat mencerminkan seberapa besar perkembangan sukuk yang telah diterbitkan oleh perusahaan kepada publik. Tujuan utama dari pemeringkatan terhadap obligasi Syariah yaitu untuk mengurangi asimetri atau ketidakseimbangan informasi antara perusahaan yang menerbitkan sukuk dengan para investor.

Hal yang perlu dilakukan oleh investor sebelum melakukan pengambilan keputusan dalam berinvestasi pada obligasi syariah, sebelumnya investor harus terlebih dahulu melihat faktor apa saja yang dapat mempengaruhi peringkat obligasi yang telah diterbitkan oleh perusahaan tersebut. Faktor tersebut dapat dilihat pada rasio keuangan perusahaan maupun faktor non keuangan. faktor yang mempengaruhi peringkat obligasi syariah yang digunakan dalam penelitian ini adalah faktor rasio keuangan seperti rasio profitabilitas, rasio likuiditas dan rasio solvabilitas.

\section{METODE PENELITIAN}

Metode yang digunakan dalam penelitian ini menggunakan metode studi kasus. Jenis data yang digunakan yaitu menggunakan data kuantitatif sedangkan sumber data pada penelitian menggunakan data sekunder yang diperoleh dari data laporan keuangan yang dipublikasikan oleh masingmasing bank berupa data profitabilitas, likuiditas, solvabilitas dan laporan peringkat sukuk yang dipublikasikan oleh PT Pefindo.

Populasi yang dipilih dalam penelitian ini adalah seluruh bank syariah yang terdaftar di Bank Indonesia periode 2016-2019 yang memiliki jumlah sebanyak 13 
perbankan syariah. Sampel merupakan suatu bagian dari jumlah dan karakteristik yang dimiliki oleh populasi tersebut (Sugiyono,2017). Teknik pengambilan sampel pada penelitian ini menggunakan metode purposive sampling. Purposive sampling merupakan teknik pengambilan sampel dengan ditentukan oleh kriteria tertentu.

Kriteria pengambilan sampel pada penelitian ini adalah :

1. Bank Syariah yang terdaftar di Bank Indonesia tahun 2016-2019.

2. Bank Syariah yang menerbitkan sukuk dan diperingktkan PT pada periode penelitian yaitu pada tahun 2016-2019.

3. Bank Syariah yang menyajikan laporan keuangan triwulan pada periode pengamatan yaitu pada tahun 2016-2019.

4. Kelengkapan data terkait dengan variabel yang diteliti yaitu variabel Profitabilitas, Likuiditas, Solvabilitas dan Peringkat Sukuk.

Sampel penelitian yang digunakan sebanyak 4 Bank Syariah.Teknik analisis yang digunakan dalam penelitian ini menggunakan analisis regresi linear berganda. Analisis regresi linear berganda pada penelitian ini digunakan karena variabel $\mathrm{X}$ pada penelitian ini memiliki jumlah lebih dari satu variabel yaitu tiga variabel. Pada penelitian ini pengujian data dilakukan dengan menggunakan program komputer SPSS 20.

\section{HASIL DAN PEMBAHASAN Analisis Regresi Linear Berganda}

Adapun hasil dari perhitungan Regresi linear berganda antara variabel independent dan dependen, yaitu variabel profitabilitas, likuiditas, dan solvabilitas terhadap peringkat obligasi syariah dapat dilihat pada tabel dibawah ini:
Tabel 1. Hasil Regresi Linear Berganda

\begin{tabular}{lrrr}
\hline Model & \multicolumn{2}{c}{$\begin{array}{c}\text { Unstandardized } \\
\text { Coefficients }\end{array}$} & $\begin{array}{c}\text { Standardized } \\
\text { Coefficients }\end{array}$ \\
\cline { 2 - 4 } & B & Std. Error & Beta \\
\hline (Constant) & 39.339 & 3.806 & \\
\hline ROA & .370 & .124 & .271 \\
\hline CR & -32.415 & 3.631 & -.848 \\
\hline DER & .231 & .064 & .355 \\
\hline Sumber $:$ data
\end{tabular}

Sumber : data diolah, 2020

Dari tabel diatas maka penelitian ini menghasilkan persamaan sebagai berikut:

$\mathrm{Y}=39,339+0,370 \mathrm{X}_{1}+(-32,415) \mathrm{X}_{2}+$ $0,231 X_{3}$

Berdasarkan persamaan diatas maka dapat diketahui bahwa nilai koefisien regresi variabel profitabilitas yang diukur menggunakan proksi ROA adalah sebesar 0,370, artinya setiap kenaikan profitabilitas 1 kali maka dapat menaikan peringkat obligasi syariah sebesar $0,370 \%$. Selanjutnya koefisiensi regresi variabel likuiditas yang diukur menggunakan proksi CR sebesar -32,415, artinya setiap penurunan likuiditas 1 kali maka dapat menurunkan peringkat obligasi syariah sebesar 32,415\%. Terakhir pada variabel solvabilitas yang diukur menggunakan proksi DER diperoleh nilai koefisien regresi sebesar 0,231, artinya setiap kenaikan Solvabilitas 1 kali maka dapat menaikan peringkat obligasi syariah sebesar $0,231 \%$.

\section{Uji T (Parsial)}

Uji statistik secara parsial (Uji T) dilakukan untuk mengetahui bagaimana pengaruh dari masingmasing variabel $\mathrm{X}$ terhadap variabel $\mathrm{Y}$, dalam melakukan pengujian pada uji $\mathrm{T}$ maka dilakukan perbandingan antara 
Nilai thitung dengan ttabel dengan tingkat kepercayaan $95 \%(\alpha=0,05)$.

Hipotesis pada penelitian ini :

$\mathrm{HO}$ : variabel profitabilitas, likuiditas dan solvabilitas secara parsial tidak berpengaruh terhadap peringkat obligasi syariah.

H0: variabel profitabilitas, likuiditas dan solvabilitas secara parsial tidak berpengaruh terhadap peringkat obligasi syariah.

Ha : variabel profitabilitas, likuiditas dan solvabilitas secara parsial berpengaruh terhadap peringkat obligasi syariah.

Dasar pengambilan keputusannya adalah sebagai berikut :Jika $t_{\text {hitung }}>t_{\text {tabel }}$, maka Ha diterima dan $\mathrm{H} 0$ ditolak

Jika $t_{\text {hitung }}<\mathrm{t}_{\text {tabel }}$, maka Ha ditolak dan H0 diterima.

Tabel 2 Hasil Uji T- Test

\begin{tabular}{llrr}
\hline $\begin{array}{l}\text { Mode } \\
1\end{array}$ & $\mathrm{~T}$ & Sig. & Model \\
\hline \multirow{3}{*}{1} & & & \\
\cline { 2 - 4 } & (Constant) & 10.335 & .000 \\
\cline { 2 - 4 } & ROA & 2.976 & .004 \\
\cline { 2 - 4 } & CR & -8.927 & .000 \\
\cline { 2 - 4 } & DER & 3.632 & .001 \\
\hline
\end{tabular}

Sumber: Data diolah, 2020

Berdasarkan hasil pengujian Uji $\mathrm{T}$ pada tabel 2 bahwa pada variabel rasio profitabilitas yang diukur menggukan proksi ROA memperoleh hasil $t_{\text {hitung }} 2,974>t_{\text {tabel }} 2,030$ dan nilai signifikan sebesar $0,004<0,05$. artinya secara parsial ROA berpengaruh positif dan signifikan terhadap rating sukuk sejalan dengan penelitian yang dilakukan oleh Utami (2016) dan Al Haraqi dan Ningsih (2017) menunjukan hasil bahwa rasio profitabilitas memberikan pengaruh signifikan positif terhadap peringkat obligasi syariah. return on asset merupakan salah satu rasio yang menggambarkan kemampuan perusahaan dengan menggunakan seluruh aktiva yang dimilikinya untuk menghasilkan sebuah laba yang optimal. Hasil penelitian ini sejalan dengan Al Haraqi (2017) yang menyatakan bahwa terdapat pengaruh signifikan positif pada rasio profitabilitas terhadap peringkat obligasi Syariah dikarenakan semakin tinggi tingkat tprofitabilitas perusahaan, maka semakin rendah resiko ketidakmampuan perusahaan dalam melakukan kewajibannya.

Rasio likuiditas yang diukur menggukan proksi CR memperoleh hasil thitung $-8,927<t_{\text {tabel }} 2,030$ dan nilai signifikan sebesar $0,000<0,05$. artinya secara parsial CR berpengaruh negatif dan signifikan terhadap rating sukuk sejalan dengan penelitian yang dilakukan. rasio likuiditas merupakan rasio yang digunakan untuk mengukur kemampuan suatu perusahaan dalam memenuhi kewajiban jangka pendek dalam waktu pembayaran yang tidak terlalu lama. Apabila perusahaan tidak mampu memenuhi kewajiban jangka pendek maka akan mempengaruhi peringkat obligasi syariah yang diterbitkan sehingga akan membuat para investor ragu untuk melakukan investasi pada obligasi syariah yang telah diterbitkan oleh perusahaan.

Rasio solvabilitas yang diukur menggukan proksi DER memperoleh hasil $t_{\text {hitung }} 3,362>t_{\text {tabel }} 2,030$ dan nilai signifikan sebesar $0,001<0,05$. artinya secara parsial DER berpengaruh positif dan signifikan terhadap rating sukuk Temuan ini sejalan dengan Mardiah (2017). Rasio solvabilitas merupakan rasio yang dapat menggambarkan kemampuan perusahaan atau bank dalam memenuhi kewajiban jangka panjang maupun jangka pendek, semakin besar kemampuan perusahaan dalam memenuhi kewajibannya maka akan semakin baik kualitas perusahaan 
tersebut. Hasil penelitian ini sejalan dengan Winanti, Nurlela dan Titisari (2017) yang menyatakan bahwa rasio solvabilitas memiliki pengaruh yang signifikan positif terhadap peringkat obligasi syariah. Perusahaan yang memiliki jumlah hutang yang rendah menandakan bahwa perusahaan tersebut mampu melunasi hutang hanya dengan modal yang dimiliki, sehingga hal ini dapat menarik perhatian para investor untuk berinvestasi, sehingga peringkat obligasi syariah akan meningkat. Dengan demikian maka dapat disimpulkan bahwa $\mathrm{H}_{1}, \mathrm{H}_{2}, \mathrm{H}_{3}$ diterima dan $\mathrm{H}_{0}$ ditolak.

\section{Uji F (Simultan)}

Uji statistik secara simultan (Uji F) dilakukan untuk mengetahui bagaimana pengaruh dari keseluruhan variabel $\mathrm{X}$ terhadap variabel $\mathrm{Y}$ pada penelitian ini, dalam melakukan pengujian pada uji $\mathrm{F}$ maka dilakukan perbandingan antara Nilai thitung dengan ttabel dengan tingkat kepercayaan $95 \% \quad(\alpha=0,05)$ dengan derajat keabsahan sebagai berikut $(\mathrm{df})=$ (k-1) (n-k) dimana k merupakan jumlah variabel penelitian dan $\mathrm{n}$ adalah jumlah sampel. Hipotesis pada penelitian ini :

H0 : variabel profitabilitas, likuiditas dan solvabilitas secara simultan tidak berpengaruh terhadap peringkat obligasi syariah.

Ha : variabel profitabilitas, likuiditas dan solvabilitas secara simultan berpengaruh terhadap peringkat obligasi syariah.

Dasar pengambilan keputusannya adalah sebagai berikut : Jika $\mathrm{F}_{\text {hitung }}<\mathrm{F}_{\text {tabel, }}$ maka Ha diterima dan $\mathrm{H} 0$ ditolak. Jika $\mathrm{F}_{\text {hitung }}>\mathrm{F}_{\text {tabel, maka } \mathrm{Ha}}$ ditolak dan $\mathrm{H} 0$ diterima.
Hasil pengujian simultan pada penelitian ini dapat dilihat pada tabel berikut ini :

Tabel 3. Hasil Uji Simultan (Uji F-Test)

\begin{tabular}{|c|c|c|c|}
\hline \multicolumn{4}{|c|}{ ANOVA $^{\mathrm{a}}$} \\
\hline Mode & & $\mathrm{F}$ & Sig. \\
\hline \multirow{3}{*}{1} & Regression & 26.800 & $.000^{\mathrm{h}}$ \\
\hline & Residual & & \\
\hline & Total & & \\
\hline
\end{tabular}

Sumber: Data diolah,2020

Dari hasil pengujian pada tabel 3 Uji F (Simultan) variabel profitabilitas (X1), likuiditas (X2) dan solvabilitas (X3) memperlihatkan bahwa nilai $f_{\text {hitung }}$ $26,800>\mathrm{f}_{\text {tabel }} 2,76$ dan nilai signifikan yang diperoleh sebesar $0,000<0,05$. Hal tersebut menyatakan bahwa Ho ditolak dan Ha diterima. Sehingga dapat ditarik kesimpulan bahwa terdapat pengaruh pada variabel indepent secara simultan terhadap variabel dependen sejalan dengan penelitian yang dilakukan oleh Mardiah (2016).

\section{Uji Koefisien Determinasi $\left(\mathbf{R}^{\mathbf{2}}\right)$}

Uji Koefisien Determinasi $\left(\mathrm{R}^{2}\right)$ dilakukan untuk menilai seberapa besar kemampuan variabel independent pada penelitian ini mempengaruhi variabel dependent. Uji Koefisien Determinasi $\left(\mathrm{R}^{2}\right)$ pada penelitian ini dapat terlihat pada tabel 4 berikut ini :

Tabel 4. Hasil Uji $\mathbf{R}^{2}$

Model Summary

\begin{tabular}{lrrrr}
\hline Model & $\mathrm{R}$ & $\mathrm{R}$ & $\begin{array}{c}\text { Adjusted R } \\
\text { Square }\end{array}$ & $\begin{array}{l}\text { Std. Error } \\
\text { of the } \\
\text { Estimate }\end{array}$ \\
\hline 1 & $.685^{\mathrm{a}}$ & .469 & .442 & 1.493 \\
\hline
\end{tabular}

Sumber : data diolah, 2020

Berdasarkan hasil tabel 4 diperoleh hasil nilai koefisien korelasi (R) sebesar 0,685 yang artinya bahwa hubungan antar variabel independen dengan variabel dependen memiliki 
hubungan yang kuat sebesar 68,5\%. Selain itu, dapat dilihat nilai koefisien determinasi yaitu sebesar 0,442 artinya kemampuan variabel rasio profitabilitas, likuiditas dan solvabilitas mempengaruhi rating sukuk sebesar $44,2 \%$ dan selisihnya $55,8 \%$ di pengaruhi oleh faktor-faktor lainnya diluar variabel independen dalam penelitian ini atau tidak masuk dalam model regresi linear.

\section{PENUTUP \\ Kesimpulan}

Berdasarkan hasil uji yang dilakukan dalam penelitian ini, maka dapat ditarik kesimpulan sebagai berikut :

1. Variabel profitabilitas secara parsial berpengaruh positif dan signfikan terhadap peringkat obligasi Syariah.

2. Variabel likuiditas secara parsial berpengaruh negatif terhadap peringkat obligasi Syariah.

3. Variabel solvabilitas berpengaruh poditif terhadap peringkat sukuk.

4. Variabel profitabilitas, likuiditas, solvabilitas secara simultan berpengaruh terhadap peringkat obligasi syariah.

\section{Saran}

Berdasarkan hasil uji yang telah dilakukan dalam penelitian ini, maka saran yang dapat diberikan oleh peneliti sebagai berikut :

1. Bagi perusahaan, Perusahaan diharapkan dapat lebih memperhatikan faktor-faktor apa saja yang dapat mempengaruhi peringkat obligasi syariah terutama dalam meningkatkan rasio keuangan perusahaan hal tersebut akan menarik minat investor untuk berinvestasi pada obligasi syariah yang diterbitkan perusahaan sehingga akan menaikan peringkat obligasi syariah yang diterbitkan.
2. Bagi investor, disarakan dalam pengambilan keputusan untuk melakukan investasi pada obligasi Syariah, investor diharapkan memperhatikan faktor-faktor yang dapat mempengaruhi peringkat sukuk sehingga dapat mengetahui kemampuan perusahaan penerbit sukuk dalam memenuhi kewajiban pada saat jatuh tempo. Investor dapat melihat peringkat dari sukuk yang diterbitkan oleh perusahaan karena semakin tinggi peringkat sukuk yang diterbitkan perusahaan maka semakin kecil perusahaan tersebut mengalami kegalalan dalam membayar dana obligasi syariah pada investor.

3. Bagi peneliti selanjutnya, diharapkan peneliti selanjutnya menggunakan periode penelitian yang lebih lama, peneliti selanjutnya dapat memperluas sampel penelitian tidak hanya pada 4 Bank Umum Syariah. peneliti berikutnya meneliti variabel independen lainnya dikarenakan penelitian ini hanya terbatas pada faktor-faktor keuangan perusahaan dalam mempredisksi peringkat Obligasi syariah, yaitu variabel profitabilitas (ROA), likuiditas (CR) dan solvabilitas (DER).

\section{DAFTAR PUSTAKA}

Al Haraqi, M. S., \& Ningsih, E. S. (2017). Pengaruh Return on Asset, Secure dan Maturity terhadap Rating Sukuk." Jurnal Ilmiah Mahasiswa Ekonomi Akuntansi 2: 116-24.

Azzatillah, P., \& Ika, M. (2019). Sukuk Yield: Secure and Maturity through Sukuk Rating. Internasional Journal of Research in Business Studies and Management 6(4): 21-28.

Hassan, M. K., Andrea, P., Dreassi, A., Miani, S., \& Sclip, A. (2018). 
The Determinants of CoMovement Dynamics between Sukuk and Conventional Bonds. Quarterly Review of Economics and Finance 68: 73-84.

Mardiah, G., Malik, Z.A., \& Nurdin. (2016). Pengaruh Likuiditas , Profitabilitas Dan Leverage Terhadap Peringkat Sukuk ( Penelitian terhadap PerusahaanPerusahaan Yang Menerbitkan Sukuk dan Terdaftar di Bursa Efek Indonesia Selama Periode...

Qizam, I., \& Fong, M. (2019). Developing Financial Disclosure Quality in Sukuk and Bond Market: Evidence from Indonesia, Malaysia, and Australia. Borsa Borsa Istanbul Review 19(3):228-48.

Sugiyono. (2017). Metodelogi Penelitian Bisnis. Ketiga. Bandung: Alfabeta

Utami, D. E. (2019). Identifiying Financial and Non Financial Factors as the Determinant of Sukuk in Indonesia." journal of Economics and Business 4:1-14.

Utami, D. E., \& Zulfa, I. (2018). Issuers' Insight for Identifying Choice of Sukuk Structuring. Jurnal Keuangan dan Perbankan 22(4): 680-93.

Widiastuty, T. (2017). Pengaruh Ukuran Perusahaan, Umur Perusahaan, Leverage dan Umur Sukuk Terhadap Peringkat Sukuk. Jurnal Riset Akuntansi 9: 21-33.

Winanti, E., Titisari, H., \& Nurlela, S. (2017). Pengaruh Rasio Likuiditas, Rasio Produktivitas, Rasio Profitabilitas, dan Rasio Solvabilitas terhadap Peringkat Sukuk. Jurnal Akuntansi dan Pajak 18(01): 130-39. 